\title{
PERFORMANCE STUDY OF SOME T.AMAN VARIETIES UNDER NORMAL TRANSPLANTING AND DOUBLE TRANSPLANTING SYSTEM
}

\author{
R. Yasmeen ${ }^{1}$, S. Akter ${ }^{1}$, T. Halder ${ }^{1}$, A. Biswas ${ }^{1}$ \\ M. M. Rahman ${ }^{2}$ and L. Ferdousi ${ }^{3}$ \\ ${ }^{1}$ Plant Physiology Division, Bangladesh Rice Research Institute (BRRI) \\ Gazipur 1701, Bangladesh \\ ${ }^{2}$ Bangladesh Agricultural Research Council (BARC), Farmgate, Dhaka \\ ${ }^{3}$ Hybrid Rice Division, Bangladesh Rice Research Institute (BRRI) \\ Gazipur 1701, Bangladesh
}

\begin{abstract}
The experiment was conducted to study the performance of three $T$. Aman varieties (BR22, BRRI dhan46 and BRRI dhan49) under normal transplanting with 30,45 and 60 days old seedlings and double transplanting ( 30 days +30 days) system at Plant Physiology Division of Bangladesh Rice Research Institute, Joydebpur, Gazipur during T. Aman season, 2013. Interaction effect was significant only for days to maximum flowering and sterility percentage. BR22 required longer duration to complete flowering when transplanted with 60 days old seedlings, while sterility percentage was higher in BRRIdhan 49 when transplanted with same aged seedlings. Photosynthetic rate, LAI, total dry matter production, yield contributing characters and harvest index of tested varieties were insignificant under different transplanting methods; these parameters contributed to produce similar grain yield. The results revealed that rice varieties $\mathrm{BR} 22, \mathrm{BRRI}$ dhan46 and BRRI dhan49 showed similar performance under normal transplanting with different aged seedlings and double transplanting in respect of photosynthetic rate, tillering pattern, LAI, total dry matter production and grain yield during T. Aman season.
\end{abstract}

Keywords: Double transplanting, growth characters, normal transplanting, rice, yield.

\section{INTRODUCTION}

Double transplanting is a crop establishment system in rice cultivation where rice seedlings are transplanted twice, first on a piece of high land, and then in the

\footnotetext{
*Corresponding author’s email: salmabrri@gmail.com
}

Received: 23.02.2016 
main field after the recession of heavy rains. It is also practiced in Boro season when main field is occupied by other crops at transplanting time. It is laborious and sometimes not economic if yield is not better than normal transplanting with same aged seedlings. However, the yield reduction of aged seedlings can be overcome by transplanting seedlings from primary to secondary nursery (Sarma et al., 2010). Simultaneously, this practice helps in producing healthy and taller seedlings that can easily overcome the adverse situation like high water depth at the time of transplanting (Rautaray, 2007; Ashim et al., 2010). In some flood-prone areas, farmers practice double transplanting (even triple transplanting) to produce taller seedlings for transplanting in standing water at the beginning of the season (India and Bangladesh) or to rejuvenate seedlings while waiting for the floodwater to recede to levels that can allow transplanting in the main field. Because Aman rice cultivation in low lying areas through double transplanting system an appropriate technology to avoid submergence problem in the flood prone areas (BRRI, 1994). Such a system with triple transplanting is practiced in Indonesia and could be further improved through the choice of proper varieties (eg., photoperiod-sensitive varieties seem to be better adapted) or proper management of seedlings in nurseries or after transplanting in the field (Ram et al., 2010). It is also said that double transplanted rice produce more yield than normal transplanting with same aged seedlings (Ashim et al., 2010; Ziagua, 2000; Satapathy, 2015). So, a comparative study of normal transplanting and double transplanting system on the basis of some growth parameters and yield is required. Therefore, this experiment was conducted to study the performance of of some T. Aman varieties under normal transplanting and double transplanting systems.

\section{MATERIALS AND METHOD}

The experiment was conducted at the Plant Physiology Division of Bangladesh Rice Research Institute (BRRI), Joydebpur, Gazipur during T. Aman season of 2013. The experimental site is located at the centre of the agroecological zone of Madhupur tract (AEZ-28). The soil belongs to the Chhiata series of the Grey Terrace soils (Aeric Albaquept) under the order Inceptisols in the USDA Soil Taxonomy (SRDI and BARC, 2005). The soil was clay loam in texture having $\mathrm{pH}$ 6.2 , organic matter content $1.3 \%$, total $\mathrm{N} 0.07 \%$, available P $22.0 \mathrm{ppm}$, exchangeable K $0.20 \mathrm{me} / 100 \mathrm{~g}$ soil and available S $44 \mathrm{ppm}$ (BRRI, 1999). Three seedling ages (30, 45 and 60 days) for normal transplanting along with double transplanting (30 days + 30 days) were studied on three T. Aman varieties (BRRIdhan49, BRRIdhan46 and BR22). Transplanting methods were treated as factor A and T. Aman varieties as factor B. The experiment was laid out in Randomized Complete Block Design with three replications. The unit plot size was $3 \mathrm{~m} \times 3 \mathrm{~m}$. For raising seedlings, sprouted seeds of all varieties were sown in the seedbed. In double transplanting system (30 days +30 days), thirty days old seedlings were transplanted at $10 \mathrm{~cm} \times 10 \mathrm{~cm}$ spacing using 9 seedlings per hill in a separate plot. After 30 days of first transplanting, the 
entire hill were uprooted and again transplanted in the main field with 2-3 tillers hill ${ }^{1}$ at $20 \mathrm{~cm} \times 15 \mathrm{~cm}$ spacing. In normal transplanting system thirty, forty five and sixty days old seedlings were transplanted at $20 \mathrm{~cm} \times 15 \mathrm{~cm}$ spacing in the main fields, respectively. Both normal transplanting and double transplanting were done in the main field on the same date at 8 August, 2013. The soil was fertilized with 90-10-35$8 \mathrm{~kg} \mathrm{ha}^{-1}$ of NPK and S in the form of urea, TSP, MOP and gypsum. The entire quantities of fertilizers except urea were applied at final land preparation. Urea fertilizer was top dressed in three splits. First and second dose was applied at 10 days and 30 days after transplanting, respectively. Third dose was applied 5-7 days before panicle initiation. Other cultural practices were done as and when required. Tillering rate was measured at 15, 30, 45 and 60 days after transplanting (DAT) by four adjacent hills basis and tiller number hill ${ }^{-1}$ was converted into tiller $\mathrm{m}^{-2}$. Photosynthesis data was taken at maximum flowering stage considering flag leaf at the middle portion using LI-6400 portable photosynthesis system. Ten hills were considered randomly from each replication for measuring photosynthesis data. For taking leaf area and dry matter weight, samplings were done at 60 and 80 DAT from the area out of the area for yield measurement. Dry matter weight was also taken at harvesting time. From leaf area data, leaf area index (LAI) was calculated according to Gomez (1972). Samples for yield components were taken from three representative hills at physiological maturity. The crop was harvested from an area of $5 \mathrm{~m}^{2}$ excluding border for yield measurement. Grain yield was adjusted at $14 \%$ moisture level and converted it to $\mathrm{t} \mathrm{ha}^{-1}$. All data were analyzed by using CROPSTAT 7.2 statistical software of IRRI.

\section{RESULTS AND DISCUSSIONS}

\section{Growth characteristics:}

Tillering pattern : Tiller number increased with the increase of age of plant up to 45 DAT and then decreased onwards in all normal planting system in all the varieties. Initially tiller number was high in double transplanting and it gradually dropped after second transplanting in all the varieties. Minimum tiller number was found after flowering stage due to death of later formed tillers (Figure 1).

Leaf area index (LAI): Maximum LAI was observed for normal transplanting with 45 days old seedlings both at 60 DAT and 80 DAT in all the varieties and other treatment combinations were statistically similar. Higher LAI at 60 DAT with 45 days old seedling was due to higher tillering density at this stage. LAI decreased with age from flowering to maturity in all the treatment combination due to leaf senescence. Higher LAI indicated more green leaf area producing more assimilates and supplied sufficient assimilates to the grains resulted reduction in grain sterility. But LAI at 80 DAT became similar both for normal transplanting and double transplanting with same aged seedling in all varieties except BR22. Zhong et al. 
(2002) stated that transplanting, spacing and number of seedlings hill $^{-1}$ had little effect on LAI (Figure 2 ).
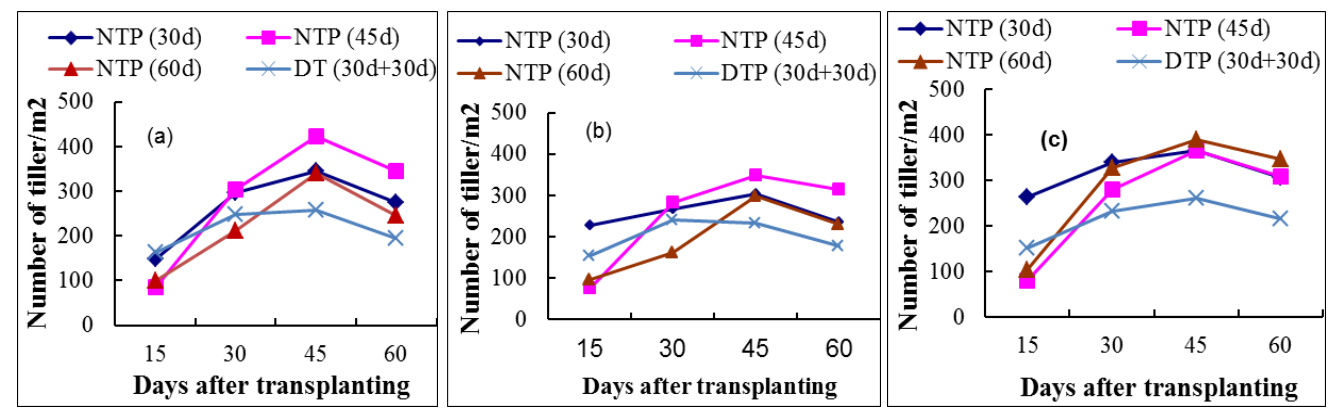

Figure 1. Tillering pattern of BRRIdhan 49 (a), BRRIdhan 46 (b) and BR22 under differing methods
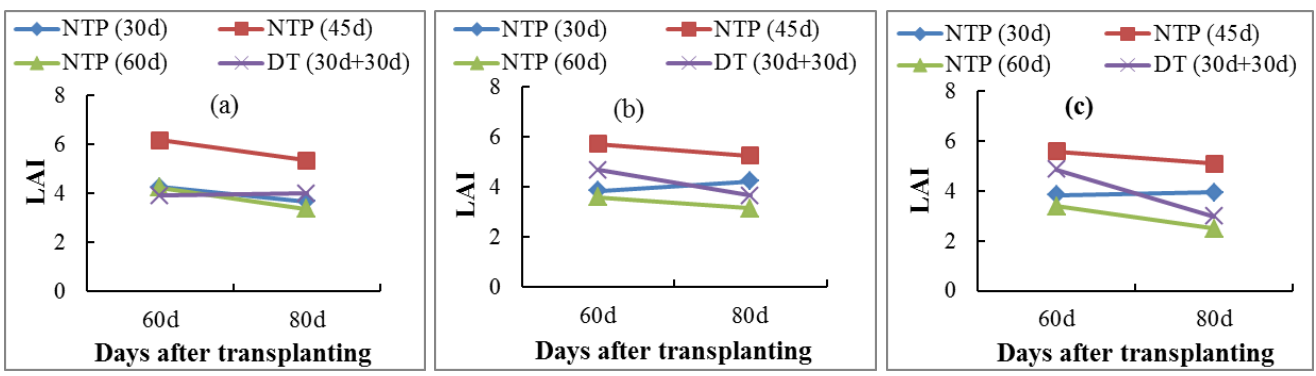

Figure 2. Leaf area index ( LAI) of BRRIdhan 49 (a), BRRIdhan 46 (b) and BR22 under differing methods

Total dry matter weight: Total dry matter weight increased with increasing age of plants in all the varieties. Total dry matter weight increased sharply up to 80 DAT, then increased slowly and at maturity it became stable. Azarpour et al. (2014) stated that maximum total dry matter accumulation was occurred at grain filling. Total dry weight is increased over time so that at early growth stages it increases with fewer gradients and in later stages, slope increasing is greater until total dry weight reaches to its maximum (grain filling). Total dry matter weight at 60 DAT, 80 DAT and at harvesting stage was statistically similar both for double transplanting and normal transplanting in all the varieties. This was happened due to similar photosynthetic rate of all the varieties at different transplanting methods (Figure 3 ). 

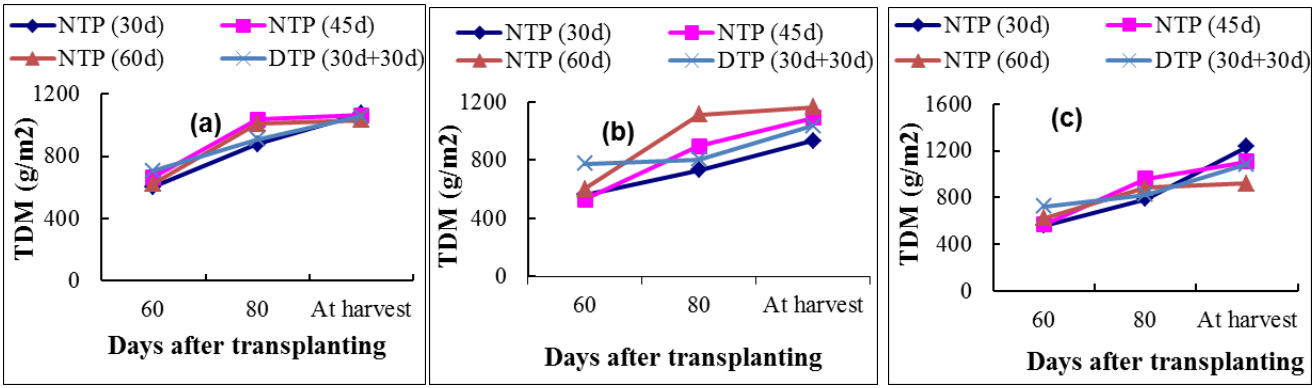

Figure 3. Total dry matter (TDM) weight of BRRIdhan 49 (a), BRRIdhan 46 (b) and BR22 under differing methods

\section{Yield and yield components}

Effect on varieties: Significant variation was present among the varieties for days to maximum flowering, number of panicles $\mathrm{m}^{-2}$, number of grains panicle $\mathrm{e}^{-1}$, 1000-grain weight and grain yield (Table 1). BR22 required more days (109 days) to attain maximum flowering stage while BRIdhan49 required less days (103 days). The highest number of panicle $\mathrm{m}^{-2}$ (235.41) was recorded in BRRIdhan49 which was statistically identical to BR22 and the lowest was obtained from BRRIdhan46. On the other hand, grain panicle ${ }^{-1}$ was maximum (127.13) in BR22 and it was similar to BRRIdhan49. Thousand grain weight of BRRIdhan46 was maximum (24.93g) but that of BRRIdhan49 and BR22 was lower. The highest grain yield $\left(5.44 \mathrm{t} \mathrm{ha}^{-1}\right)$ was observed in BRRI dhan49 which was at par with BR22 and the lowest yield was found in BRRI dhan46 (Table 1). Maximum grain yield in BRRIdhan49 was due to higher number of panicle $\mathrm{m}^{-2}$ and grain per panicle. Hassan et al. (2003) also reported that grain yield is a function of interplay of various yield components such as number of productive tillers, spikelets per panicle and 1000-grain weight.

Table 1. Effect of varieties on photosynthesis, yield and yield components

\begin{tabular}{l|c|c|c|c|c|c|c|c}
\hline Variety & $\begin{array}{c}\text { Photosyn- } \\
\text { thesis } \\
(\mu \mathrm{molCO} \\
\left.\mathrm{m}^{-2} \mathrm{~s}^{-1}\right)\end{array}$ & $\begin{array}{c}\text { Days to } \\
\text { maximum } \\
\text { flowering } \\
(\mathrm{no})\end{array}$ & $\begin{array}{c}\text { Panicle } \\
\mathrm{m}^{-2} \\
(\text { no. })\end{array}$ & $\begin{array}{c}\text { Grain } \\
\text { panicle } \\
(\mathrm{no} .)\end{array}$ & $\begin{array}{c}1000- \\
\text { grain } \\
\text { weight } \\
(\mathrm{g})\end{array}$ & $\begin{array}{c}\text { Grain } \\
\text { yield }(\mathrm{t} \\
\left.\mathrm{ha}^{-1}\right)\end{array}$ & $\begin{array}{c}\text { Sterility } \\
(\%)\end{array}$ & $\begin{array}{c}\text { Harvest } \\
\text { index }\end{array}$ \\
\hline $\begin{array}{l}\text { BRRI } \\
\text { dhan49 }\end{array}$ & 20.72 & 103 & 235.41 & 118.02 & 18.42 & 5.44 & 23.53 & 0.48 \\
$\begin{array}{l}\text { BRRI } \\
\text { dhan46 }\end{array}$ & 20.45 & 105 & 204.86 & 97.44 & 24.93 & 4.97 & 26.43 & 0.46 \\
BR22 & 20.70 & 109 & 218.05 & 127.13 & 19.14 & 5.42 & 22.58 & 0.48 \\
\hline LSD $(0.05)$ & $\mathrm{NS}$ & 1.42 & 26.06 & 14.58 & 1.52 & 0.42 & $\mathrm{NS}$ & $\mathrm{NS}$ \\
\hline $\mathrm{CV}(\%)$ & 9.00 & 1.80 & 12.90 & 14.00 & 8.60 & 10.40 & 18.40 & 5.50 \\
\hline
\end{tabular}

$\mathrm{NS}=$ Not significant 
Effect of transplanting methods: Photosynthetic rate, days to maximum flowering, number of panicles $\mathrm{m}^{-2}$ and number of grain panicle ${ }^{-1}$ varied significantly due to transplanting methods (Table 2). Photosynthetic rate decreased with increasing seedling age but it was maximum in double transplanting system. Days to maximum flowering, number of panicle $\mathrm{m}^{-2}$ increased but number of grain panicle ${ }^{-1}$ decreased with the increase of seedling age. Grain yield variations among the varieties due to transplanting methods were insignificant. This was occurred due to combined effect of number of panicle $\mathrm{m}^{-2}$ and grain per panicle (Table 2).

Table 2. Effect of planting methods on photosynthesis, yield and yield components

\begin{tabular}{l|c|c|c|c|c|c|c|c}
\hline Variety & $\begin{array}{c}\text { Photosyn- } \\
\text { thesis } \\
\left(\mu \mathrm{molCO}_{2}\right. \\
\left.\mathrm{m}^{-2} \mathrm{~s}^{-1}\right)\end{array}$ & $\begin{array}{c}\text { Days to } \\
\text { maximum } \\
\text { flowering } \\
(\text { no. })\end{array}$ & $\begin{array}{c}\text { Panicle } \\
\mathrm{m}^{-2} \\
(\text { no. })\end{array}$ & $\begin{array}{c}\text { Grain } \\
\text { panicle } \\
(\text { no. })\end{array}$ & $\begin{array}{c}1000- \\
\text { grain } \\
\text { weight } \\
(\mathrm{g})\end{array}$ & $\begin{array}{c}\text { Grain } \\
\text { yield } \\
\left(\mathrm{t} \mathrm{ha}^{-1}\right)\end{array}$ & $\begin{array}{c}\text { Sterility } \\
(\%)\end{array}$ & $\begin{array}{c}\text { Harvest } \\
\text { index }\end{array}$ \\
\hline NTP (30 DAS) & 20.28 & 103 & 186.11 & 119.23 & 21.00 & 5.04 & 22.90 & 0.42 \\
NTP (45 DAS) & 20.00 & 106 & 217.59 & 111.91 & 20.32 & 5.63 & 22.96 & 0.44 \\
NTP (60 DAS) & 19.82 & 107 & 266.66 & 98.89 & 21.50 & 5.20 & 27.04 & 0.53 \\
DT (30 +30) DAS & 22.40 & 107 & 207.40 & 126.76 & 20.50 & 5.24 & 23.82 & 0.49 \\
\hline LSD $_{(0.05)}$ & 1.83 & 1.67 & 30.10 & 16.83 & $\mathrm{NS}$ & $\mathrm{NS}$ & $\mathrm{NS}$ & $\mathrm{NS}$ \\
\hline $\mathrm{CV}^{(\%)}$ & 9.00 & 1.80 & 12.90 & 14.00 & 8.60 & 10.40 & 18.40 & 5.50 \\
\hline
\end{tabular}

NTP $=$ Normal transplanting, DT $=$ Double transplanting, DAS $=$ Days after seeding

NS =Not significant

Effect of interaction: Significant variation was observed for days to maximum flowering and sterility percentage among all treatment combinations. Other parameters including grain yield were statistically similar (Table 3, 4 \& 5). Maximum days to complete flowering was observed in BR22 at normal transplanting with 60 days aged seedlings followed by double transplanting. Minimum days to complete flowering was observed in BRRI dhan 49 at normal transplanting with 30 days old seedlings. The variation among the treatment combinations for maximum flowering may be due to varietals factors In this study, grain yield variation was insignificant for all the treatment combinations due to resultant effect of number of panicle $\mathrm{m}^{-2}$ and grain per panicle. This result showed dissimilarity with the findings of Ashem et al. (2010). But these characters are closely associated with some yield contributing characters as LAI, total dry matter weight, productive tiller, harvest index and so on. The highest percentage of sterility was observed in normal transplanting with 60- day old seedlings of BRRIdhan49 followed by double transplanting of BRRIdhan 46 and the lowest in the plant which was transplanted with 30- day old seedlings of BRRI dhan49. The highest sterility percentage was due to 
late producing tiller which flowered later and produced inferior spikelets. These spikelets were filled slowly and poorly and ultimately produced unfilled grain.

Table 3. Interaction effect of variety and planting method on photosynthesis, days to maximum flowering and panicle $\mathrm{m}^{-2}$ during T. Aman season, 2013

\begin{tabular}{|c|c|c|c|c|c|c|c|c|c|}
\hline \multirow{3}{*}{$\begin{array}{l}\text { Planting } \\
\text { method }\end{array}$} & \multicolumn{9}{|c|}{ Variety } \\
\hline & \multicolumn{3}{|c|}{$\begin{array}{l}\text { Photosynthesis } \\
\left(\mu \mathrm{molCO}_{2} \mathrm{~m}^{-2} \mathrm{~s}^{-1}\right)\end{array}$} & \multicolumn{3}{|c|}{$\begin{array}{c}\text { Days to maximum flowering } \\
\text { (no.) }\end{array}$} & \multicolumn{3}{|c|}{$\begin{array}{l}\text { Panicle } \mathrm{m}^{-2} \\
\quad \text { (no.) }\end{array}$} \\
\hline & $\begin{array}{c}\text { BRRI } \\
\text { dhan49 }\end{array}$ & $\begin{array}{c}\text { BRRI } \\
\text { dhan46 }\end{array}$ & BR22 & $\begin{array}{c}\text { BRRI } \\
\text { dhan49 }\end{array}$ & $\begin{array}{c}\text { BRRI } \\
\text { dhan46 }\end{array}$ & BR22 & $\begin{array}{c}\text { BRRI } \\
\text { dhan49 }\end{array}$ & $\begin{array}{l}\text { BRRI } \\
\text { dhan46 }\end{array}$ & BR22 \\
\hline NTP (30 DAS) & 19.63 & 20.50 & 20.73 & 95 & 104 & 109 & 200.00 & 163.88 & 194.44 \\
\hline NTP (45 DAS) & 21.03 & 18.76 & 20.20 & 104 & 105 & 107 & 227.77 & 211.11 & 213.88 \\
\hline NTP (60 DAS) & 18.05 & 20.20 & 21.23 & 105 & 107 & 111 & 275.00 & 261.11 & 263.88 \\
\hline $\begin{array}{l}\text { DT(30+ } \\
\text { 30)DAS }\end{array}$ & 24.16 & 22.36 & 20.66 & 107 & 104 & 109 & 238.88 & 183.33 & 200.00 \\
\hline $\operatorname{LSD}_{(0.05)}$ & & NS & & & 3.2 & & & 47.83 & \\
\hline $\mathrm{CV}(\%)$ & & 9.00 & & & 1.8 & & & 12.90 & \\
\hline
\end{tabular}

NTP $=$ Normal transplanting, DT $=$ Double transplanting, DAS $=$ Days after seeding

NS =Not significant

Table 4. Interaction effect of variety and planting method on grain panicle ${ }^{-1}, 1000-$ grain weight and grain yield during T. Aman season, 2013

\begin{tabular}{|c|c|c|c|c|c|c|c|c|c|}
\hline \multirow{3}{*}{$\begin{array}{l}\text { Planting } \\
\text { method }\end{array}$} & \multicolumn{9}{|c|}{ Variety } \\
\hline & \multicolumn{3}{|c|}{$\begin{array}{c}\text { Grain panicle }{ }^{-1} \\
\text { (no.) }\end{array}$} & \multicolumn{3}{|c|}{$\begin{array}{l}\text { 1000-grain weight } \\
\text { (g) }\end{array}$} & \multicolumn{3}{|c|}{ Grain yield $\left(\mathrm{t} \mathrm{ha}^{-1}\right)$} \\
\hline & $\begin{array}{c}\text { BRRI } \\
\text { dhan49 }\end{array}$ & $\begin{array}{c}\text { BRRI } \\
\text { dhan46 }\end{array}$ & BR22 & $\begin{array}{c}\text { BRRI } \\
\text { dhan49 }\end{array}$ & $\begin{array}{c}\text { BRRI } \\
\text { dhan46 }\end{array}$ & BR22 & $\begin{array}{r}\text { BRRI } \\
\text { dhan49 }\end{array}$ & $\begin{array}{c}\text { BRRI } \\
\text { dhan46 }\end{array}$ & BR22 \\
\hline NTP (30 DAS) & 132.67 & 94.92 & $\begin{array}{c}130.0 \\
9\end{array}$ & 19.15 & 25.00 & 18.84 & 4.69 & 4.71 & 5.72 \\
\hline NTP (45 DAS) & 115.84 & 90.01 & $\begin{array}{c}129.8 \\
9\end{array}$ & 18.52 & 23.33 & 19.11 & 5.25 & 5.76 & 5.87 \\
\hline NTP (60 DAS) & 106.14 & 92.57 & 97.96 & 17.89 & 27.49 & 19.12 & 5.10 & 5.62 & 4.89 \\
\hline $\mathrm{DT}(30+30) \mathrm{DAS}$ & 117.41 & 112.28 & 150 & 18.14 & 23.89 & 19.48 & 4.85 & 5.65 & 5.21 \\
\hline $\operatorname{LSD}_{(0.05)}$ & \multicolumn{3}{|c|}{ NS } & \multicolumn{3}{|c|}{ NS } & \multicolumn{3}{|c|}{ NS } \\
\hline$\overline{\mathrm{CV}(\%)}$ & \multicolumn{3}{|c|}{14.00} & \multicolumn{3}{|c|}{8.60} & \multicolumn{3}{|c|}{10.4} \\
\hline
\end{tabular}

NTP $=$ Normal transplanting, DT $=$ Double transplanting, DAS $=$ Days after seeding

NS =Not significant 
Table 5. Interaction effect of variety and planting method on sterility and harvest index during T. Aman season, 2013

\begin{tabular}{l|c|c|c|c|c|c}
\hline \multirow{2}{*}{$\begin{array}{l}\text { Planting } \\
\text { method }\end{array}$} & \multicolumn{7}{|c}{ Variety } \\
\cline { 2 - 7 } & BRRI dhan49 & BRRI dhan46 & BR22 & $\begin{array}{c}\text { BRRI } \\
\text { dhan49 }\end{array}$ & $\begin{array}{c}\text { BRRI } \\
\text { dhan46 }\end{array}$ & BR22 \\
\cline { 2 - 7 } & & 25.33 & 26.93 & 0.47 & 0.40 & 0.53 \\
\hline NTP 30 DAS) & 16.43 & 26.38 & 19.23 & 0.41 & 0.47 & 0.48 \\
NTP (45 DAS) & 23.27 & 26.47 & 23.71 & 0.38 & 0.50 & 0.47 \\
NTP (60 DAS) & 30.95 & 27.54 & 20.45 & 0.45 & 0.56 & 0.52 \\
DT (30 + 30)DAS & 23.47 & 7.92 & \multicolumn{5}{c}{ NS } \\
\hline LSD $(0.05)$ & \multicolumn{7}{c}{5.50} \\
\hline CV (\%) & 18.40 & \\
\hline
\end{tabular}

NTP $=$ Normal transplanting, DT $=$ Double transplanting, DAS $=$ Days after seeding

NS =Not significant

\section{CONCLUSION}

The results revealed that rice varieties BR22, BRRI dhan 46 and BRRI dhan49 showed similar performance under normal transplanting with different aged seedlings and double transplanting in respect of photosynthetic rate, tillering pattern, LAI, total dry matter production and grain yield during T. Aman season.

\section{REFERENCES}

Azarpour, E., Moraditochaee, M., and Bozorgi, H. R. 2014. Effect of nitrogen fertilizer management on growth analysis of rice cultivars. International Journal of Biosciences, Vol.4, No. 5, p.35-47

Ashim, S. S., Thakuria, K. and Kurmi, K. 2010. Double transplanting of late transplanted sali rice under lowland situation. Oryza, 47(4): 328-330

BARC. 2005. Fertilizer Recommendation Guide-2005, vol. 45 of Soils Pub., Bangladesh Agricultural Research Council, Farmgate, Bangladesh

Bangladesh Rice Research Institute.1998. Annual Report for 1994. Bangladesh Rice Res. Inst. Gazipur-1701. pp: 260

Evanglista, P. P., Panaullah, G. M., Mazid, M. A., Rahman, M. S., Saleque, M. A., Ishaque, M. and Saha, P. K. 1999. Soil survey of Bangladesh Rice Research Institute Farm, Gazipur-1701. pp:7

Hassan, G., Khan, N. U., Khan, Q. N. 2003. Effect of transplanting date on the yield and yield components of different rice cultivars under high temperature of D.I. Khan. Sci Khy.; 16(2):129-137

Gomez, K. A. 1972. Techniques for field experiments with rice. The International Rice Research Institute, Los Banos, Philippines. 
Ram, P. C., Mazid, M. A., Ismail, A. M., Singh, P. N., Singh, V. N., Haque, M. A., Singh, U., Ella, E. S. and Singh, B. B. 2010. Crop and resource management in flood-prone areas: farmers' strategies and research Development," In: S. M. Haefele and A. M. Ismail, Eds., Proceedings Natural Resource Management for Poverty Reduction and Environmental Sustainability in Fragile Rice-Based Systems, Los Baňos (Philippines), International Rice Research Institute, 2009, pp. 82-94

Rautaray, S. K. 2007. Strategies for crop production in flood affected areas of Assam. Indian Farming, 57(6): 23-26

Sarma, U. J., Bhattacharyya, H.C. and Chakravarty, M. 2010. Performance of rice variety 'Ranjit' under staggered and double transplanted condition. International Journal of Agricultural Statistical Science, 6(2): 435-40

Satapathy, B. S., Sing, T., Pun, K. B., Rautary, S. K. 2015. Evaluation of rice (Oryza sativa) under double transplanting in rainfed lowland rice ecosystem of Asom. Indian Journal of Agronomy, 60 (2): 245-248

SRDI. 2005. "Bhumi and Mrittika Sampad Bhavohar Nirdeshika, Gazipur Sadar Upazila, Gazipur Zilla," Soil Resources Development Institute. Ministry of Agriculture, Government of the Peoples Republic of Bangladesh

Ziagua, Z. 2000. Rice-wheat cropping system in China. Soil and Crop Management Practices for Rice-Wheat Cropping System in Siachin Province of China, RWC paper series 9. Hobbs, P.R. and Gupta, P.K. (Eds.), Rice-wheat Consortium for IndoGangetic Plains, India

Zhong, X., Peng S., Sheehy J. E., Visperas R. M., Liu H. 2002. Relationship between tillering and leaf area index: quantifying critical leaf area index for tillering in rice. Journal of Agricultural Sciences, 138(3):269-279 